\title{
Implementation of Marketing Communication Strategy for Alcoholic Products in Social Sensitivity and Legal Protection
}

\author{
Mahesa Maulana ${ }^{1}$, Rachmat Kriyantono ${ }^{2}$, Bambang Dwi Prasetyo ${ }^{3}$ \\ 1,2,3Universitas Brawijaya, Malang, Indonesia \\ Email: mahesa@student.ub.ac.id
}

\begin{abstract}
The role of marketing communication strategy is very important for companies in marketing products to their target market. Marketing communication of alcoholic beverage products which is hampered by promotion, marketing and distribution requires the right strategy in its implementation to ensure business continuity. This research has an exploratory constructivist paradigm. The purpose of this study was to determine the strategy carried out by the management of PT. Multi Bintang Indonesia as a marketing communication strategy for Bir Bintang alcoholic beverages. The research data collection method is through in-depth interviews, observation, and documentation. The data analysis of this research is descriptive qualitative. Informant data collection technique is purposive sampling at the Area Business Manager and Business Development Executive PT. Multi Bintang Indonesia Commerce. The results of the study reveal that the company's strategy is more focused on online aspects, including the use of social media, websites and e-commerce to inform products, sales, and campaigns. The form of marketing communication carried out by PT. Multi Bintang Indonesia in the form of direct and interactive marketing, sales promotion, event marketing, merchandise, personal selling, public relations, and word of mouth.
\end{abstract}

Keywords: Marketing communication strategy, Alcoholic beverage, SOSTAC.

\section{A. INTRODUCTION}

The era of information transformation, makes communication an absolute must in delivering messages between individuals and organizations for information needs. In the current era of global competition, companies are required to develop strategies and determine effective and creative marketing communication programs to be able to compete with other competitors (Rangkuti, 2013), as well as develop dialogue and build relationships with consumers (Kotler \& Armstrong, 2018).

A marketing communication strategy is needed for each institution in order to carry out the process of identifying the right target audience, market selection, and market segments (Assauri, 2013); and marketing plans are developed for the selected market segments, so that the needs of target consumers can be met (Machfoedz, 2010).

In carrying out marketing communication activities, companies sometimes encounter obstacles or obstacles that come from external to the company. Likewise, companies that produce alcoholic beverages are faced with several obstacles, both socio-religious, and regulations at the local, regional, and national levels.

The facts show that consumers of alcoholic beverages in a country with a majority Muslim population are spread across various regions other than in provinces where the majority of the population is non-Muslim. Meanwhile, the demand for beer 
as an alcoholic beverage is quite high in Southeast Asia, sales and consumption of beer increased by 34\% from year to year (Damayanti, 2020; Ansori, 2021). The beer beverage industry has also provided employment for 240,000 people in Indonesia (Detikfinance, 2013).

Maintaining the availability of employment from the beverage industry and its derivatives is closely related to the ability of company management in developing promotion, marketing and distribution strategies so that; (i) does not rub against socio-cultural issues that are prone to politicization and often hinder, and (ii) operate under formal regulations at both regional and national levels.

One of the alcoholic beverage industries experiencing marketing barriers is PT. Multi Bintang Indonesia Tbk. The company was founded in 1921 in Medan which is a subsidiary of Heineken based in the Netherlands. On November 21, 1931, the first brewery in Surabaya officially operated, in 1936 the company was moved to the city of Surabaya with the largest shareholder being Heineken. In 1997 production activities in Surabaya were moved to Sampang Agung, Mojokerto, East Java. A long history in Indonesia, the company is identified with one of the flagship products, namely Bir Bintang, an iconic brand that is widely known in Indonesia. Bintang beer is a type A drink with an alcohol content of $1-5 \%$ such as Prost, Bali Hai, Anker, Diablo, Draft, and Stout products. With strong brewery activities in Sampang Agung and Tangerang, the company markets and sells its products in all major cities in Indonesia and abroad through its subsidiary PT. Multi Bintang Indonesia Niaga which acts as the main distributor.

Marketing communication activities are hampered because of the Regulation of the Minister of Trade of the Republic of Indonesia Number 20 of 2014 concerning Control and Supervision of the Procurement, Circulation, and Sales of Alcoholic Beverages, in Article 30 which reads IT-MB, distributors, sub distributors, direct sellers, and retailers are prohibited from advertising alcoholic beverages in any mass media. This causes the alcoholic beverage industry to only be able to carry out promotions in certain places such as entertainment or dining venues that comply with existing regulations. As in the Regulation of the Minister of Trade Number 20 of 2014 Article 14 paragraphs 1-3 which explains the sale of alcoholic beverages to drink on the spot or to take home can be sold in restaurants, hotels, bars, duty-free shops, minimarkets, supermarkets, hypermarkets in accordance with statutory government regulations.

Control and supervision of the sale of alcoholic beverages, because it has a negative impact on public health. According to the World Health Organization (WHO), the negative impact on the world community caused 3 million people in the world to die with a ratio of 1 in 20 deaths in the world caused by alcohol consumption in 2016 (CNN Indonesia, 2018). In addition to having a negative impact on health, alcoholic beverages are allegedly an indicator of increasing criminal acts in the form of persecution, threatening, immoral acts, theft, bullying, extortion, and immoral acts (Lestari, 2016), and accidents (Kompas, 2012). Regulation of the Minister of Health of the Republic of Indonesia Number: 86/Men.Kes/Per/IV/77 concerning alcoholic 
beverages is stipulated to regulate the use of alcoholic beverages that can cause health problems, production, and distribution. Meanwhile, Law Number 39 of 2007 stipulates alcoholic beverage products as excisable goods whose distribution is controlled which of course burdens the company (Directorate General of Customs and Excise, 2015). On the other hand, Law no. 25 of 1999 concerning the financial balance between the Central and Regional Governments which is implemented in the form of Government Regulation no. 25 of 2000 concerning the Authority of the Government and the Authority of the Province as an autonomous region is also a barrier to product distribution. In addition to the existence of control and supervision, alcoholic beverage products are also opposed by various anti-alcohol movements. This has resulted in a number of strong rejections by Islamic organizations against alcoholic beverages, even through illegal raids accompanied by anarchic actions (Berita Satu, 2012; Hamdi, 2016).

Internationally, alcoholic beverages have also been refused production, distribution and consumption in several countries where the majority of the population is Muslim, such as Malaysia since 1998 which regulates the age limit for consumption and the application of a fairly high alcohol tax, namely 15\% - 100\% (Setiaji, 2018), in the United Arab Emirates, carrying or consuming alcoholic beverages must have a permit issued by the government and the sale of alcoholic beverages is found in tourist attractions (Subekti, 2016; Assegaf, 2016), and Turkey prohibits alcoholic beverage companies from sponsoring various events in Turkey (Hardoko , 2013). Meanwhile, in several countries where the majority of people are non-Muslims, restrictions and regulations are also carried out firmly. In India, Vietnam, and Sri Lanka there is a prohibition on promotion in the form of advertisements on TV and radio (Assunta, 2001).

Promotion through advertising is an important strategy in marketing communications. In Indonesia, alcoholic beverage products are prohibited from advertising their products in the mass media, but promotions are allowed in entertainment venues, and places determined by regulations are regulated by the Regent/Mayor and Governor.

If we review research on the promotion of alcoholic beverages in other countries, most researchers such as Stacy et al. (2004), Snyder et al. (2006), and Nelson (2011), focus on how advertising can affect the interest and level of consumption, both at adulthood or legal age, as well as at a young age or the age where it is prohibited to drink alcoholic beverages. Not only through advertising in the media, promotion of alcoholic beverages is carried out through various events such as sports activities (Gee et al. 2016), sponsorship of activities (Musante et al. 1999) and through videos and music concerts (Primack et al. 2012). Promotion or marketing can be through the appearance of product packaging (Celhay et al. 2019) and advertising language (Sillani et al. 2017). To increase brand awareness and sales, research by Dolan and Goodman (2017), uses digital marketing through social media Facebook to conduct marketing communications for wine products. In addition to advertising promotions, the alcoholic beverage industry is promoting through an Integrated Marketing 
Communication (IMC) approach. This can be seen in the research of Reid et al. (2015) who found how the wine industry in Australia and New Zealand used the IMC approach to face global market competition. In Australia the alcoholic beverage industry still has a license to market its products, the marketing strategy used is advertising both traditional and non-traditional media through television, merchandise, billboards, newspapers, and magazines (Faulkner et al., 2017).

Alcoholic beverage producers in Indonesia also have a strategy to promote their products in the midst of various prohibitions and circulation controls. However, in Indonesia there is not much promotion and variety of mass communication in introducing alcoholic beverage products. Promotion of alcoholic beverages in Indonesia will be more effective if directed through a pricing strategy program (Ratnasari \& Anityasari, 2015), customer loyalty and distribution strategies (Kodrat, 2007). Thus it appears that the alcoholic beverage industry in Indonesia and countries with a majority Muslim population cannot conduct marketing communications through mass communication. So far, there is no research on integrated marketing communication strategies in Indonesia related to alcoholic beverages. In contrast to cigarette products, which are excisable goods, they are still free to carry out marketing communication activities. To prove these assumptions, researchers need to prove these assumptions through empirical research and seek the truth of these assumptions.

For this reason, an approach using the SOSTAC model analysis is needed to identify and explore the marketing communication strategy of Bir Bintang products. The analysis of the SOSTAC model is an analytical knife that is often used in marketing planning in a business context. A successful marketing plan is based on and integrated with traditional marketing, planning techniques, and marketing communications (Chaffey \& Smith, 2017). Through SOSTAC analysis, researchers can find out how the marketing communication strategy is carried out by the company, as well as efforts to find out a comprehensive and integrated marketing plan based on the principles of SOSTAC analysis.

This research reveals the marketing communication strategy for Bir Bintang products, as well as effective marketing communication strategies for alcoholic beverage products. Thus, from this research, it is hoped that the implementation of marketing communications in the business domain and management of excisable goods products is based on a marketing communication strategy in dealing with regulations that hinder the marketing process, in addition to being able to apply a situation, objectives, strategy, tactics, action, and control analysis model in the realm of marketing communications.

The purpose of this research with the theme of marketing communication strategy is to describe the marketing communication strategy for Bir Bintang products by analyzing Situation, Objectives, Strategy, Tactics, Action, and Control. In addition, to describe an effective marketing communication strategy for alcoholic beverage products. 
Based on the introduction above, the research questions can be formulated as follows: How is the implementation of the marketing communication strategy for Bir Bintang products?.

\section{B. METHODS}

This study uses a constructivist paradigm, using a qualitative approach that is flexible and open to changes and adjustments during research so that there are no limits for researchers to determine new things related to the research topic.

(Bungin, 2007). This qualitative research aims to explain the phenomenon through the collection of deep data (Kriyantono, 2014). Data that emerges from qualitative research that has an exploratory nature, namely exploring describes a situation or phenomenon related to what the researcher is studying. With this approach, this research produces descriptive data in the form of written or oral data from the marketing communication strategy of Bintang Beer products carried out by the management of the company PT. Multi Bintang Indonesia Tbk. (Moleong, 2018; Creswell \& Creswell, 2018).

In general, the focus of this research is to find out the marketing communication strategy for Bintang Bir products at PT. Multi Bintang Indonesia Tbk. Specifically, this study aims to: (1) Explain how to analyze the situation in marketing communication strategies; (2) Explaining the analysis of objectives in the marketing communication strategy; (3) Explaining the strategy analysis on the marketing communications carried out; (4) Analysis of tactics on marketing communication strategies; (5) Action analysis on marketing communication strategy; and (6) control analysis on marketing communication strategy.

In this study, researchers used primary and secondary data sources. This primary data was obtained with interview instruments and secondary data, among others, obtained through literature studies, written documents and archives related to the object under study. The subjects of this research are Area Bisuness Manager and Business Development Executive PT. Multi Bintang Indonesia Niaga - Regional Sales Office (East Java). PT. Multi Bintang Indonesia Niaga Regional Sales Office (East Java) is one of the subsidiaries that carries out marketing activities in the East Java and surrounding areas. While the object of this research is the marketing communication strategy for Bintang beer products by PT. Multi-Star Indonesia.

Data collection techniques through documentation/library and in-depth interviews conducted in a focused and in-depth manner. This study uses a purposive sampling technique (Kriyantono, 2020), including people who are selected on the basis of criteria made by researchers based on research objectives.

Data analysis was carried out referring to the interactive model (Miles, Huberman, \& Saldana, 2014), which consisted of several stages, namely data collection, data condensation, data presentation, and verification/drawing conclusions. 


\section{RESULTS AND DISCUSSION}

Based on the results of in-depth interviews, observations, and documentation studies on the marketing communication strategy for Bir Bintang products using the SOSTAC method, it can be stated how the strategies carried out by the company from strategic planning to implementation and evaluation stages in marketing their products, as follows.

\section{Beer Bintang Communication Strategy}

In developing effective communication, Kotler \& Armstrong (2018), stated that there are several stages starting from identifying the target audience, setting goals, designing communications, choosing channels, and setting a budget. In addition, the communication strategy carried out by the organization towards the audience is to build knowledge, a pleasant attitude and care (Kriyantono, 2017). The company's communication strategy for Bir Bintang products takes into account the identification of the target audience, goals, message strategies, media strategies to the required budget. The target audience is adjusted to the provisions of existing regulations, one of which is to determine the target age of 21+. The company's goal is to become a company with a good reputation and responsibility in accordance with the company's vision and mission. As a company that is responsible for its products, the company always displays warnings about the dangers of alcohol to pregnant women, consumption while driving and warnings that beer can only be consumed by people aged $21+$.

The appeal conveyed by the company is one of the messages to inform consumers. In addition, the content of the communication or message conveyed by the company is to present Bir Bintang products through taglines, images, and descriptions. The type of message that Multi Bintang Indonesia uses is transformational appeal or emotional appeal. This is exemplified in the tagline "Stars to be together", which means that stars are very suitable when gathering with friends, family, and friends to create a relaxed and fun atmosphere. Transformational attraction includes negative attraction including: guilt, fear, shame; and positive attractions include: love, humor, pride, and joy (Kotler \& Keller, 2016). The stronger the attractiveness of the communication message, the more positive consumer attitudes towards the brand will be (Rai, 2013; Feiz et al., 2013; Nasution et al., 2014). Silalahi (2018) and Sadeghi, et al (2015) state that emotional or transformational appeal is more suitable for low involvement products, while rational appeal is more effective for high involvement products.

In delivering messages, communicators who are influential, famous, and credible are needed. One source of messages or messengers from outside the company, namely celebrities, influencers and chefs who are credible and quite popular in Indonesia. The company uses message sources that are considered to have good credibility and influence.

The selection of media used by Multi Bintang Indonesia is more online-based to introduce products, such as through websites, social media (Instagram, linkidn, facebook, and youtube), and e-commerce (bli-bli.com, shopee.com, tokopedia.com, 
bukalapak.com, happyfresh.id, lazada.co.id, Gofood, and grab food). Company communication media, such as websites and other social media, need to provide interactive information, and two-way communication, this is useful for meeting satisfaction and needs when accessing the website as a means of subsidy information (Kriyantono, 2020).

\section{Beer Bintang Marketing Communication Strategy with SOSTAC Model}

The analytical model used in this study is Chaffey and Smith's SOSTAC model (2017) which consists of situation, objectives, strategy, tactics, action and control which will be explained below.

\section{a. Situation}

Multi Bintang Indonesia is a company that has a long history in Indonesia, a company that is synonymous with its superior product, Bir Bintang, which has become iconic and widely known in Indonesia. The latest product innovation is through Bintang Radler, a combination of Bintang Beer with lemon and orange variants. Iconic products that have a long history in Indonesia, as well as the innovation of new variants are the main attractions of Bir Bintang.

At the stage of situation analysis, discussing how the condition of the product in the market both internally and externally from the product. To analyze the product internally and externally, a SWOT analysis is required (Table 1) consisting of internal analysis: strength, weakness; and external analysis: Opportunities, Threats.

\section{Table 1. SWOT Analysis of Bintang Beer Products}

\begin{tabular}{|c|c|c|}
\hline No & Strength & Weakness \\
\hline 1 & Quite strategic distribution & $\begin{array}{l}\text { The price is quite expensive among } \\
\text { other type A alcohol products }\end{array}$ \\
\hline 2 & $\begin{array}{l}\text { Exports to } 4 \text { continents namely Asia, } \\
\text { Europe, Australia and the United } \\
\text { States }\end{array}$ & Brand Perception \\
\hline 3 & $\begin{array}{l}\text { The oldest brand with history in } \\
\text { Indonesia since } 1931\end{array}$ & $\begin{array}{l}\text { Lack of distribution in the eastern part } \\
\text { of Indonesia, especially Papua } \\
\text { Province. }\end{array}$ \\
\hline 4 & Good company credibility & \\
\hline 5 & $\begin{array}{l}\text { Product quality: products made } \\
\text { from selected and quality materials }\end{array}$ & \\
\hline 6 & $\begin{array}{l}\text { Have quality and modern } \\
\text { technology }\end{array}$ & \\
\hline & Opportunity & Threats \\
\hline 1 & Cooperation with other companies & $\begin{array}{l}\text { Regulations regarding the control and } \\
\text { supervision of the procurement, } \\
\text { circulation, and sale of alcoholic } \\
\text { beverages. }\end{array}$ \\
\hline 2 & Regional Regulations & Have competent competitors \\
\hline
\end{tabular}




\begin{tabular}{|c|l|l|}
\hline 3 & The target market is still quite large. & $\begin{array}{l}\text { Consumers can choose other types of } \\
\text { alcohol drinks }\end{array}$ \\
\hline 4 & & $\begin{array}{l}\text { Contaminated liquor products that } \\
\text { have a negative impact on the legal } \\
\text { alcoholic beverage industry. }\end{array}$ \\
\hline 5 & $\begin{array}{l}\text { A hardline anti-alcohol society } \\
\text { organization and a culture that } \\
\text { opposes alcoholic beverages. }\end{array}$ \\
\hline
\end{tabular}

Source: Processed by researchers (2020)

\section{b. Objective}

After knowing the internal and external situation of Bintang Beer products, of course a product or company has its own purpose. The goal of the Bintang Beer company or product is to create good performance, be responsible and become a leading beer brand. The stages of this goal will be summarized by the SMART model, consisting of specific, measurable, achievable, relevant, timed by adjusting the results of interviews and research observations, as explained below:

Table 2. SMART Model of Bintang Beer Product

\begin{tabular}{|c|c|c|c|}
\hline No. & SMART GOALS & Detail & \\
\hline 1 & Specific & $\begin{array}{l}\text { 1. What do I want? } \\
\text { 2. Why is this goal } \\
\text { important? } \\
\text { 3. Who is involved? } \\
\text { 4. Where is it located? } \\
\text { 5. Which resources or } \\
\text { limits are involved? }\end{array}$ & 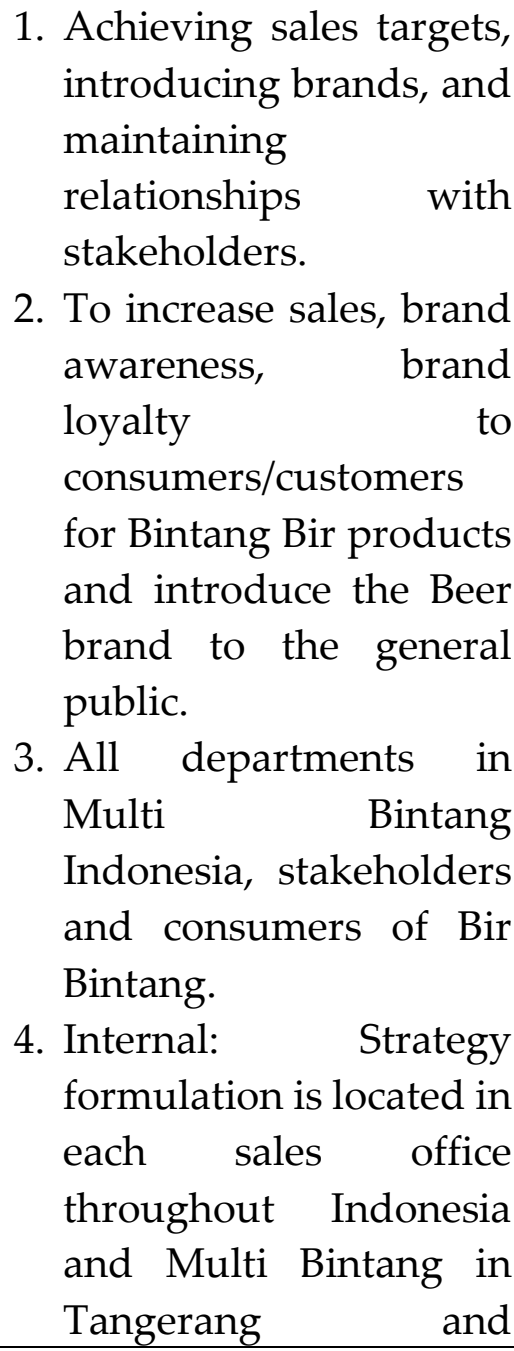 \\
\hline
\end{tabular}




\begin{tabular}{|c|c|c|c|}
\hline & & & 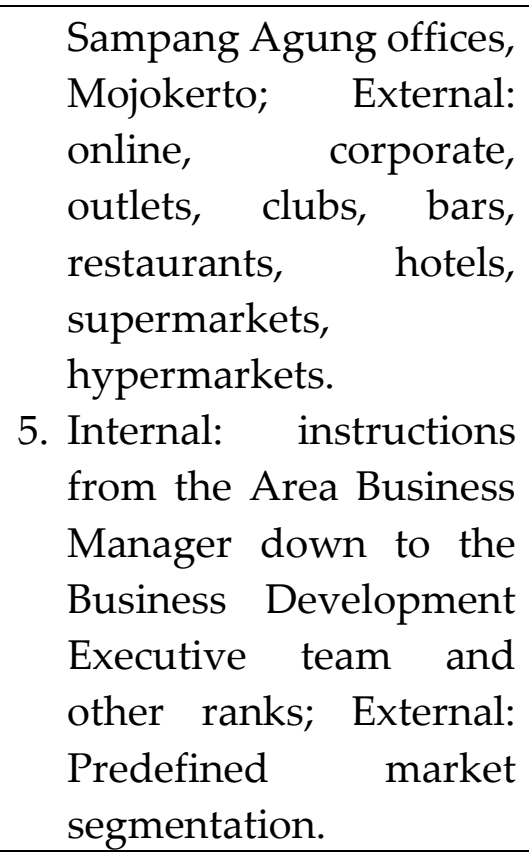 \\
\hline 2 & Measurable & Measurable goals & $\begin{array}{l}\begin{array}{l}\text { Online segmentation } \\
\text { through } \\
\text { e-commerce, }\end{array} \\
\text { corporate, customers who } \\
\text { come to outlets, hotels, } \\
\text { restaurants to drink. }\end{array}$ \\
\hline 3 & Achievable & $\begin{array}{l}\text { Goals are realistic and } \\
\text { achievable }\end{array}$ & $\begin{array}{l}\text { Marketing Bintang beer } \\
\text { products in general in the } \\
\text { beer class, both consumers, } \\
\text { potential customers who } \\
\text { come directly to outlets or } \\
\text { online purchases, become } \\
\text { responsible products to } \\
\text { consumers, and offer prices } \\
\text { that are in accordance with } \\
\text { international beer quality. }\end{array}$ \\
\hline 4 & Relevant & $\begin{array}{l}\text { Reassure the company } \\
\text { regarding the } \\
\text { importance of goals for } \\
\text { the company itself. }\end{array}$ & $\begin{array}{l}\text { Introducing Bintang Beer } \\
\text { to the target market and } \\
\text { providing promotional } \\
\text { offers, several Beer } \\
\text { variants, and attractive } \\
\text { packaging. }\end{array}$ \\
\hline 5 & Time Bound & $\begin{array}{l}\text { Prioritize } \\
\text { predetermined and } \\
\text { designed deadlines. }\end{array}$ & $\begin{array}{l}\text { Each goal of the marketing } \\
\text { communication strategy } \\
\text { carried out by Bir Bintang } \\
\text { has different deadlines, } \\
\text { according to the program } \\
\text { of activities or events that }\end{array}$ \\
\hline
\end{tabular}




\begin{tabular}{|l|l|l|}
\hline $\mid$ & $\begin{array}{l}\text { have been designed. For } \\
\text { large/annual events, } \\
\text { preparations are carried } \\
\text { out approximately 3 } \\
\text { months in advance. As for } \\
\text { the event every 3 months, } \\
\text { the preparation is done for } \\
\text { about 1 month. For } \\
\text { monthly events, make } \\
\text { preparations } \\
\text { approximately 2 weeks in } \\
\text { advance. }\end{array}$ \\
\hline
\end{tabular}

Source: Data processed by researchers (2020)

\section{c. Strategy}

The next stage is strategy, in this stage there are three main elements, namely segmentation, targeting, and positioning, as well as a series of communication tools. First, the Bir Bintang market segmentation is $21+$, male and female, middle economic class. Second, targeting, the company mobilizes the sales team to have its own target, as for several things the sales team does, namely visiting outlets, corporates, agencies. Third, positioning, Bir Bintang products are classified as international quality drinks with moderate prices. Market share data is needed for companies, because this is useful to make it easier to evaluate performance, develop innovation and market expansion.

Communication tools are used by the company through a pull strategy including through interactive marketing such as content on social media or the company's website, as well as posters found at product sales points, CSR activities, perfect stores, events and push strategies including direct marketing, merchandise. The strategy carried out by the company is through marketing activities as an effort by the company to establish relationships with its audience and adapt to the local local culture. (Kriyantono \& Sa'diyah, 2018).

\section{d. Tactics}

After knowing the company's strategy, the next step is tactics. At this tactical stage, using the marketing mix, to support the strategy that has been developed, is shown in the table below.

Table 3. Marketing Mix of Bintang Beer Products

\begin{tabular}{|c|c|c|c|}
\hline No & Marketing Mix & Bintang Beer & Information \\
\hline 1 & Product & BINTANG PILSENER & $\begin{array}{l}\text { Bintang Pilsener has an alcohol } \\
\text { content of } 4.7 \% \mathrm{~V} / \mathrm{V} \text { in several } \\
\text { packages, including: } \\
\text { - } 620 \mathrm{ml} \text { bottles and } 330 \mathrm{ml} \text { bottles, } \\
\text { - } 500 \mathrm{ml} \text { cans and } 330 \mathrm{ml} \text { cans, } \\
\text { - Draft } 20 \text { liters, and } 30 \text { liters. }\end{array}$ \\
\hline
\end{tabular}




\begin{tabular}{|c|c|c|c|}
\hline & & $\underbrace{}_{\text {BINTANG RADLER }}$ & $\begin{array}{l}\text { Bintang Radler has an alcohol } \\
\text { content of } 2 \% \mathrm{~V} / \mathrm{V} \text {, with the Radler } \\
\text { Orange and Radler Lemon variants } \\
\text { in several packages including: } \\
330 \mathrm{ml} \text { bottles and } 330 \mathrm{ml} \text { cans. }\end{array}$ \\
\hline 2 & Price & $\begin{array}{l}\text { Bintang Pilsener } \\
\text { Bintang Redler }\end{array}$ & $\begin{array}{l}\text { Bottles } \\
620 \mathrm{ml}: \operatorname{Rp} 35.000 \\
330 \mathrm{ml}: \operatorname{Rp} 30.000 \\
\text { Cans } \\
500 \mathrm{ml}: \operatorname{Rp} 27.000 \\
330 \mathrm{ml}: \operatorname{Rp} 29.000 \\
\text { Draft } \\
20-30 \text { liter } \\
\pm \text { Rp } 1.500 .000-\operatorname{Rp} 2.500 .000 \\
\text { Bottles } \\
330 \mathrm{ml}: \operatorname{Rp} 18.700 \\
\text { Cans } \\
330 \mathrm{ml}: \operatorname{Rp} 19.100\end{array}$ \\
\hline 3 & Place & $\begin{array}{l}\text { The production sites for } \\
\text { Bintang products are in } \\
\text { Tangerang, West Java } \\
\text { and Sampang Agung, } \\
\text { East Java. Sales Office } \\
\text { and distribution in every } \\
\text { city in Indonesia. }\end{array}$ & $\begin{array}{l}\text { Bintang Pilsener and Bintang } \\
\text { Redler Beer Alcohol, can be sold } \\
\text { including at: } \\
\text { Bar, Café, Restaurant, Club, Hotel, } \\
\text { Supermarket or Hypermarket in } \\
\text { accordance with the provisions of } \\
\text { each regional regulation. }\end{array}$ \\
\hline 4 & Promotion & (2) & 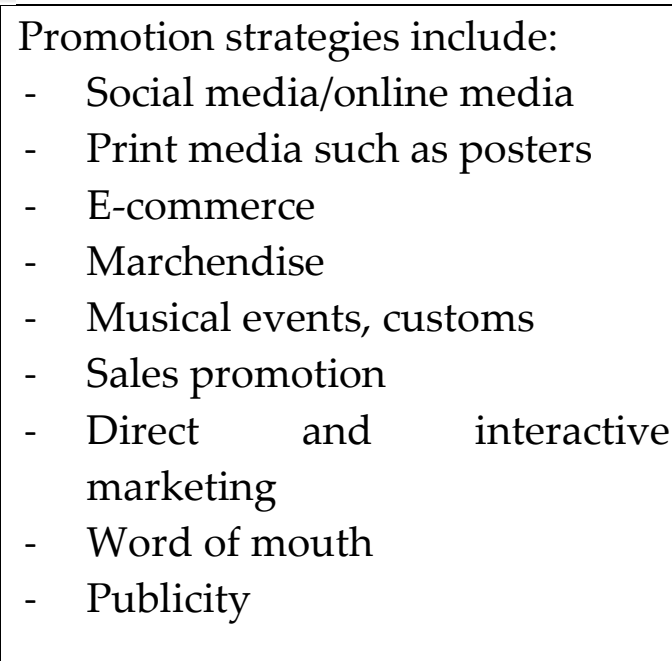 \\
\hline
\end{tabular}




\begin{tabular}{|c|c|c|c|}
\hline 5 & People & $\begin{array}{l}\text { Management PT. Multi } \\
\text { Bintang Indonesia }\end{array}$ & $\begin{array}{l}\text { - Central management holds a } \\
\text { meeting with the Area Business } \\
\text { Manager every } 3 \text { months to } \\
\text { evaluate the activities carried } \\
\text { out. } \\
\text { - Weekly meeting of Area } \\
\text { Business Manager with sales to } \\
\text { improve the program and } \\
\text { progress of marketing activity } \\
\text { programs. } \\
\text { Once a year, the company's } \\
\text { management conducts training } \\
\text { to improve } \\
\text { performance, both knowledge } \\
\text { and skills. }\end{array}$ \\
\hline 6 & Process & $\begin{array}{l}\text { Multi Bintang employees } \\
\text { ensure that the supply of } \\
\text { goods (products) at } \\
\text { outlets has met, branded } \\
\text { Bintang outlets, provides } \\
\text { facilities needed for } \\
\text { outlets such as } \\
\text { refrigerators, glasses, } \\
\text { promo posters, } \\
\text { merchandise }\end{array}$ & \\
\hline 7 & Physical Evidence & & $\begin{array}{l}\text { - The company creates a perfect } \\
\text { store by considering attractive } \\
\text { designs and layouts, strategic } \\
\text { places, and visibility. } \\
\text { - The company communicates } \\
\text { incentives to consumers } \\
\text { through distinctive products, } \\
\text { product logos with packaging, } \\
\text { beer draft tools, standing logos, } \\
\text { logo lights. } \\
\text { - The company provides } \\
\text { uniforms in one color with } \\
\text { product logos/labels. }\end{array}$ \\
\hline
\end{tabular}

Source: Data processed by researchers (2020)

In this tactical stage, the company must pay attention to and have a good relationship with the media, this is considered very important to get optimal broadcasting (Kriyantono, 2016). Company management or public relations requires 
journalists as audiences, mediators, gatekeepers to convey information and respond to public needs and build a positive image (Kriyantono, 2017).

\section{e. Actions}

Actions carried out through social media owned by the company, starting from building, developing and managing to optimize the implementation of the tactics that have been designed. Optimization of social media to build a brand to reach the market through posts by introducing their products. Next, develop content, through social media that users often use and include links on each social media so that they can visit the company's website. It also includes hashtags to group content and make it easier to search, product branding, product promotion and cross-platform campaigns. Managing social media content by providing interesting, communicative information and as an interaction between brands and consumers. Determine the schedule for uploading social media content within the time specified by the company.

\section{f. Control}

This control stage is to monitor and measure the company's strategy for Bir Bintang products, as well as analyze brand awareness, market share, sales volume, to consumer engagement and sales through digital marketing media channels. In addition, the company also receives complaints both on services and products from consumers or customers, so as to improve the quality of services and products.

Through this SOSTAC model the company can find out how to optimize the strategy carried out both from determining market segmentation, target market, positioning and measuring or controlling which activities/programs are quite well implemented by the company. The strategy carried out by the company such as through product branding is a process to find out the product image, which can build brand loyalty, and can encourage high brand equity (Kriyantono, 2020). Branding itself involves elements of products, services, and company branding that act as elements that extend to various products that are related or not and have a diversity of customers (Wibowo, Prasetyo, \& Kriyantono 2020).

The marketing communication strategy carried out by the beverage industry aims to attract and encourage consumers to buy the product. Bir Bintang implements several push and pull strategies, such as what was done with Han Dynastea soft drink products using push and pull strategies to introduce and sell their products, marketing communication activities such as providing good service, product variants, member rewards for customers and attractive logos as its brand mark (Sari \& Setyanto, 2019). Marketing communication strategy in this modern era, Multi Bintang Indonesia uses social media and online media for its promotional activities. The same thing was done for Brandish beverage products, using social media as one of the promotional activities to achieve consumer loyalty (Surya \& Kurniawan, 2018). Unlike the case with coca-cola beverage products, this product uses a television advertising strategy to attract consumers with the theme of fun and togetherness, as well as the target market for young people (Ardhianto \& Kurniawan, 2016; Setiawati, 2017). In addition to 
alcoholic beverages, marijuana products originating from Colorado are not free to do marketing, this product is promoted through the official Marijuana website, and most of the promotions carried out by stakeholders are through word of mouth (WOM) both between advocacy groups and between state governments (Kang, O'Leary \& Miller, 2016).

\section{CONCLUSION}

The SOSTAC method can be used to evaluate marketing communication strategies carried out by companies or products to determine strategies that will suit the characteristics and conditions of the product or company. Through the SOSTAC method, it can be seen that the marketing communication strategy carried out by PT. Multi Bintang Indonesia for Bintang Beer products. The strategy carried out by the company follows the development of digital technology, namely through online such as utilizing social media, websites and e-commerce to inform products and product sales. Offline strategies through distribution channels such as take away sales or drinking at places that have been determined by the government, including pubs, bars, clubs, hotels, tourist attractions, retail shops, supermarkets and restaurants.

The form of marketing communication conducted by PT. Multi Bintang Indonesia is more below the line (BTL) such as promotions through direct and interactive marketing, sales promotion, marketing events, merchandise, personal selling, publicity, word-of-mouth. In formulating strategies, the company considers socio-cultural, demographic and applicable regulations. The company is also committed to being a good and responsible company through CSR programs and campaigns.

So far, marketing communication activities carried out by the alcoholic beverage industry in Indonesia include sales promotion, public relations, marketing events, word of mouth, and merchandise. To reach its target market, the alcoholic beverage industry expands product distribution channels both online through ecommerce or social media and offline including through retail stores, pubs, clubs, bars, tourist attractions, and supermarkets.

The researcher hopes that this research can contribute to the scientific field of marketing communication, as well as as a reference for planning marketing communication strategies for products that have obstacles to regulations, socioculture and demographics from an area or a country.

\section{REFERENCES}

1. Ansori, A. (2021). Angka Konsumsi Alkohol Asia Tenggara Meningkat 34 Persen. Retrieved from https://www.liputan6.com/health/read/4506391/angkakonsumsi-alkohol-asia-tenggara-meningkat-34-persen-bagaimana-di-indonesia

2. Ardhianto, P., \& Kurniawan, M. (2016). Strategi iklan produk coca-cola di Indonesia dalam mempertahankan dan menguatkan citra. Jurnal Widya Sosiopolitika, 7(2), 91-106.

3. Assauri, S. (2013). Marketing management. Jakarta, Rajawali Pers. 
4. Assegaf, F. (2016, Juni 25). Buat pertama kali, Dubai izinkan minuman beralkohol dijual siang selama Ramadan. Retrieved from https://albalad.co/pelesir/2016A6145/buatpertama-kali-dubai-izinkan-minuman-beralkohol-dijual-siang-selama-ramadan/

5. Assunta, M. (2001). Impact of alcohol consumption on Asia. The Globe, 3(4).

6. Berita Satu. (2012). Polisi Cegah FPI Berbuat Anarkis. Retrieved from https://www.beritasatu.com/nasional/50945/polisi-cegah-fpi-berbuat-anarkis

7. Bungin, B. (2007). Penelitian kualitatif: komunikasi, ekonomi, kebijakan publik, dan ilmu sosial lainnya (Vol. 2). Kencana.

8. Celhay, F., Cheng, P., Masson, J., \& Li, W. (2019). Package graphic design and communication across cultures: An investigation of Chinese consumers' interpretation of imported wine labels. International Journal of Research in Marketing, 37(1), 108-128.

9. Chaffey, D., \& Smith, P. R. (2017). Digital marketing excellence: planning, optimizing and integrating online marketing. Taylor \& Francis.

10. CNN Indonesia. (2018). WHO: 1 dari 20 Kematian di Dunia Disebabkan Konsumsi Alkohol. Retrieved from https://www.cnnindonesia.com/gayahidup/20180924092831-255-332635/who-1-dari-20-kematian-di-dunia-disebabkankonsumsi-alkohol

11. Damayanti, A. (2020). Produksi Bir Corona Disetop. Retrieved from https://finance.detik.com/industri/d-4974816/produksi-bir-corona-disetop

12. Detikfinance. (2013). Industri Bir Serap 240.000 Tenaga Kerja. Retrieved from https://finance.detik.com/industri/d-2171086/industri-bir-serap-240000-tenagakerja

13. Direktorat Jendral Bea dan Cukai. (2015). Official Website Direktorat Jenderal Bea dan Cukai. Retrieved from https://www.beacukai.go.id/arsip/cuk/cukai.html

14. Dolan, R., \& Goodman, S. (2017). Journal of Hospitality and Tourism Management Succeeding on social media: Exploring communication strategies for wine marketing. Journal of Hospitality and Tourism Management, 33, 23-30. https://doi.org/10.1016/j.jhtm.2017.09.001

15. Faulkner, A., Azar, D., \& White, V. (2017). 'Unintended' audiences of alcohol advertising: exposure and drinking behaviors among Australian adolescents. Journal of Substance Use, 22(1), 108-112. https://doi.org/10.3109/14659891.2016.1143047

16. Feiz, D., Fakharyan, M., Jalilvand, M. R., \& Hashemi, M. (2013). Examining the effect of TV advertising appeals on brand attitudes and advertising efforts in Iran. Journal of Islamic Marketing.

17. Gee, S. (2016). Carnivalesque culture and alcohol promotion and consumption at an annual international sports event in New Zealand. 51(3), 265-283. https://doi.org/10.1177/1012690214522461

18. Hamdi, I. (2016). Polisi Bubarkan Razia Minuman Keras Oleh Ormas di Depok Ramadan Tempo.co. Retrieved from https://ramadan.tempo.co/read/785087/polisibubarkan-razia-minuman-keras-oleh-ormas-di-depok 
19. Hardoko, E. (2013). Parlemen Turki Sahkan Undang-undang Anti-alkohol. Retrieved from

https://travel.kompas.com/read/2013/05/24/16561286/parlemen.turki.sahkan.un dang-undang.anti-alkohol

20. Kang, S. K., O'Leary, J., \& Miller, J. (2016). From forbidden fruit to the goose that lays golden eggs: Marijuana tourism in Colorado. Sage Open, 6(4), https://doi.org/10.1177/2158244016679213

21. Kodrat, D. S. (2007). Perencanaan strategi marketing industri minuman beralkohol untuk menciptakan sustainable competitive advantage. 2002.

22. Kompas. (2012). Alkohol dan Ekstasi Ganggu Kesadaran. Retrieved from https://health.kompas.com/read/2012/01/24/0749112/alkohol.dan.ekstasi.ganggu .kesadaran

23. Kotler, P., \& Armstrong, G. (2018). Principles of marketing. Pearson Publisher.

24. Kotler, P., \& Keller, K. L. (2016). Marketing management. Pearson Publisher.

25. Kriyantono, R., \& McKenna, B. (2017). Developing a culturally-relevant public relations theory for Indonesia. Jurnal Komunikasi: Malaysian Journal of Communication, 33(1).

26. Kriyantono, R., \& Sa'diyah, H. (2018). Kearifan lokal dan strategi komunikasi public relations di BUMN dan perusahaan swasta. Jurnal Ilmu Komunikasi:Universitas Atma Jaya Yogyakarta, 15(2)

27. Kriyantono, R. (2020). Efektivitas website perguruan tinggi negeri sebagai penyedia informasi bagi mahasiswa. Jurnal Studi Komunikasi, 4(1), 117-142.

28. Kriyantono, R. (2020). Aplikasi teori osgood untuk evaluasi pemaknaan internal strategi komunikasi pemasaran co-branding. Jurnal Ilmu Komunikasi, 17(2), 193204.

29. Kriyantono, R. (2014). Teknik praktis riset komunikasi. Prenada Media.

30. Kriyantono, R. (2016). Public relations writing. Jakarta: Prenada Media.

31. Kriyantono, R. (2017). Teori-Teori Public Relations Perspektif Barat E Lokal: Aplikasi Penelitian \& Praktik. Kencana.

32. Lestari, T. P. R. (2016). Questioning the regulation on consumption of alcoholic beverages in Indonesia. 07(02), 127-141.

33. Machfoedz, M. (2010). Komunikasi Pemasaran Modern. Yogyakarta: Cakra Ilmu.

34. Moleong, L. J. (2018). Metodologi Penelitian Kualitatif. Jakarta: Remaja Rosdakarya.

35. Multi Bintang Indonesia. (2019). Annual report. Retrieved from https://multibintang.co.id/uploads/annual reports/5e1aa98515ee232edca9138eec2 1e566.pdf

36. Musante, M., Milne, G. R., \& McDonald, M. A. (1999). Sport sponsorship: Evaluating the sport and brand image match. International Journal of Sports Marketing \& Sponsorship, 1(1), 32-48.

37. Nasution, R. P., Sulistyowati, L., \& Marhadi, M. (2014). Analisis pengaruh kreatifitas iklan, daya tarik iklan, dan kredibilitas endorser Terhadap brand attitude pada produk Nokia Asha di kota Pekanbaru. Riau University.

38. Nelson, J. P. (2011). What is learned from longitudinal studies of advertising and 
youth drinking and smoking? A Critical Assessment. 870-926. https://doi.org/10.3390/ijerph7030870

39. Peraturan Menteri Perdagangan Republik Indonesia Nomor 20 Tahun 2014 tentang Pengendalian dan Pengawasan terhadap Pengadaan, Peredaran, dan Penjualan Minuman Beralkohol.

40. Primack, B. A., Nuzzo, E., Rice, K. R., \& Sargent, J. D. (2012). Alcohol brand appearances in US popular music. Addiction, 107(3), 557-566.

41. Rai, N. (2013). Impact of advertising on consumer behaviour and attitude with reference to consumer durables. International Journal of Management Research and Business Strategy, 2(2), 74-79.

42. Rangkuti, F. (2013). Strategi Promosi yang Kreatif dan Analisis Kasus. Jakarta: Gramedia Pustaka Utama.

43. Ratnasari, D., \& Anityasari, M. (2015). Analisis swot ud. $x$, ukm pembuat minuman beralkohol 1). 1-8.

44. Reid, M., Johnson, T., Ratcliffe, M., Skrip, K., Wilson, J. (2015). Integrated marketing communications in the Australian and New Zealand wine industry Integrated marketing communications in the Australian and New Zealand wine industry. 0487(January). https://doi.org/10.1080/02650487.2001.11104889

45. Sari, M. P., \& Setyanto, Y. (2019). Strategi komunikasi pemasaran PT. Han Indotama Perkasa dalam memperkenalkan brand minuman Han Dynastea. Prologia, 3(1), 182-189.

46. Setiawati, L. (2017). Efektivitas strategi pemasaran PT. Coca Cola Amatil Indonesia (PT. Ccai) melalui promosi iklan televisi versi "rasakan momennya" pada produk minuman ringan coca-cola (Study kasus pada Karang Taruna kelurahan Serua, Tangerang Selatan) (Doctoral dissertation, Universitas Pamulang).

47. Sillani, S., Miccoli, A., \& Nassivera, F. (2017). Author's accepted manuscript different preferences for wine communication. Wine Economics and Policy. https://doi.org/10.1016/j.wep.2017.03.002

48. Snyder, L. B., Milici, F. F., Slater, M., Sun, H., \& Strizhakova, Y. (2006). Effects of alcohol advertising exposure on drinking among youth. 160, 18-24. https://doi.org/10.1001/archpedi.160.1.18

49. Stacy, A. W., Zogg, J. B., Unger, J. B., \& Dent, C. W. (2004). Exposure to televised alcohol ads and subsequent adolescent alcohol use. American Journal of Health Behavior, 28(6), 498-509.

50. Subekti, S. (2016). Pertama, Dubai Longgarkan Aturan Minuman Beralkohol Selama Ramadhan - Satu Harapan. Retrieved from https://www.satuharapan.com/readdetail/read/pertama-dubai-longgarkan-aturan-minuman-beralkohol-selamaramadhan

51. Surya, M. D., \& Kurniawan, F. (2018, February). The effectiveness of marketing communication through digital content for startup business (Case Study: Brandish beverage product). In 4th Bandung Creative Movement International Conference on Creative Industries 2017 (4th BCM 2017) (pp. 308-312). Atlantis Press.

52. Wibowo, A. T., Prasetyo, B. D., \& Kriyantono, R. (2020). The influence of halal 
tourism destination branding on visitors satisfaction and revisit intention (a study of domestic tourist in Lombok, West Nusa Tenggara). Media Bina Ilmiah, 14(4), 2431-2440. 